\title{
1 Tetracapsuloides bryosalmonae abundance in river water
}

2

3 Running page head: $T$. bryosalmonae abundance in river water
5

6

7

8

9

Fontes, I. ${ }^{1,2,3,4}$, Hartikainen, H. ${ }^{3,4}$, Holland, Jason W. ${ }^{2}$, Secombes, Chris J. ${ }^{2}$ and Okamura, B. ${ }^{{ }^{*}}$

${ }^{1}$ Department of Life Sciences, Natural History Museum, Cromwell Road, London SW7 5BD, UK

${ }^{2}$ Scottish Fish Immunology Research Centre, University of Aberdeen, Aberdeen AB24 2TZ, UK

${ }^{3}$ Eawag, Swiss Federal Institute of Aquatic Science and Technology, Dübendorf, Switzerland

${ }^{4}$ ETH Zürich, Institute of Integrative Biology (IBZ), Zürich, Switzerland

*Corresponding author: b.okamura@nhm.ac.uk

\section{Abstract}

Tetracapsuloides bryosalmonae is a myxozoan parasite of freshwater bryozoans and salmonids, causing proliferative kidney disease in the latter. To date, detection of the parasite requires collection of hosts and subsequent molecular or histological examination. The release of infectious spores from both hosts offers an opportunity to detect the parasite in water samples. We developed a SYBR ${ }^{\circledR}$ Green quantitative real-time PCR (qPCR) assay for T. bryosalmonae in water samples which provides an estimation of bryozoan malacospore numbers and tested the assay in three rivers in southern England over a period of five weeks. The assay proved to be both highly sensitive and specific to the parasite, detecting low levels of spores throughout the study period. Larger volume samples afforded greater detection likelihood, but did not increase the number of spores detected, possibly as a result of low and patchy spore distributions and lack of within-site replication of large volume samples. Based on point-measurements, temperature was positively associated with the likelihood of detecting spores, possibly reflecting the temperature dependence of spore shedding from bryozoan hosts. The presence of $T$. bryosalmonae in water samples was predominantly influenced by spatial (sites within rivers, amongst rivers) and temporal (sampling dates) factors, while the latter also influenced $C_{q}$ values and spore abundance. Environmental monitoring for infectious stages can complement traditional methods, providing faster and easier detection and avoiding potentially prolonged searching, collecting and destructive sampling of invertebrate and vertebrate hosts.

Keywords: Proliferative Kidney Disease; Myxozoa; qPCR; environmental DNA; disease risk 


\section{Introduction}

Emerging aquatic diseases pose threats to biodiversity, conservation and sustainable use of freshwater resources (Okamura \& Feist 2011). Monitoring parasites and pathogens over appropriate temporal and spatial scales is therefore crucial for understanding and predicting the conditions that lead to disease outbreaks. However, detecting infections in the absence of clinical disease and mortality can be challenging and problematic. For example, for many fish diseases, detection involves destructive sampling of already threatened host species and may require numerous individuals to be killed to gain confidence in the results. Time-consuming histopathology or tissue-targeted molecular approaches may then be required to verify parasite presence. As an alternative approach and a complementary tool, molecular detection of parasite DNA in environmental samples is increasingly employed in marine and freshwater environments (Audemard et al. 2006, Hung \& Remais 2008, Strand et al. 2014). Thus, the detection and quantification of disease agents in environmental samples offers a unique potential to inform on the ecology and epidemiology of host-parasite interactions by circumventing traditional parasitological approaches. With these advantages in mind, we have developed a quantitative real-time PCR (qPCR) assay to detect and characterise, from water samples, the abundance of Tetracapsuloides bryosalmonae. This myxozoan causes proliferative kidney disease (PKD) in salmonids - a disease that has been increasing in prevalence and severity, particularly in fish farms, and whose distribution has been expanding with environmental change.

Tetracapsuloides bryosalmonae is an endoparasite of freshwater bryozoans and salmonids, causing PKD in both wild and farmed fish in Europe (Wahli et al. 2007) and North America (Ferguson \& Needham 1978). Tetracapsuloides, Buddenbrockia and several undescribed species form the Malacosporea (Fiala et al. 2015), a small and early diverging clade of myxozoans (Canning et al. 2000). T. bryosalmonae spores (referred to as malacospores: Feist et al. 2015) released in the urine of fish measure some $16 \mu \mathrm{m}$ in width and $14 \mu \mathrm{m}$ in height (Kent \& Hedrick 1986, Hedrick et al. 2004, Bettge et al. 2009) and are infective to freshwater bryozoans (Morris \& Adams 2006, Grabner \& El-Matbouli 2008). In bryozoans the parasite forms sacs (up to $350 \mu \mathrm{m}$ in diameter) filled with many thousands of spherical spores of approximately 20 $\mu \mathrm{m}$ in diameter (Canning et al. 2000, McGurk et al. 2005, Okamura et al. 2011). Malacospores released from sacs are ejected from bryozoans and remain infectious to 
fish for 12-24h (Feist et al. 2001, De Kinkelin et al. 2002). The smaller spores of $T$. bryosalmonae released from fish possess two capsulogenic cells, a single sporoplasm and two valve cells (Morris \& Adams 2008). The larger spores released from bryozoans have four capsulogenic cells, two sporoplasms, and some eight or ten valve cells (Feist et al. 2015). Little is known about the timing of malacospore release from bryozoan and fish hosts nor of variation in spore abundance in natural systems. In bryozoan hosts, spore production has been observed to occur predominantly in spring and autumn (Tops et al. 2006), which should lead to increased spore concentrations in water at these times. However, because naïve fish become infected in other seasons, spores released from bryozoans are likely to be present year-round (Gay et al. 2001). The presence of sporogonic stages (pseudoplasmodia in kidney tubules) in naturally-infected fish has been described as rare and spores are estimated to be released in numbers that will be greatly diluted in the natural environment (maximum concentration estimate $=120$ spores $/ \mathrm{ml}$ urine) $($ Hedrick et al. 2004).

Detection of T. bryosalmonae currently includes searching for and collection of patchily distributed freshwater bryozoans, followed by qualitative PCR to confirm infection or examining dissected bryozoans for spore-producing sacs. Detection of infection in wild fish typically involves electrofishing, dissection and subsequent histopathology or conducting PCR/qPCR of fish tissues (e.g. Grabner \& El-Matbouli 2009, Kumar et al. 2013). qPCR assays to detect and quantify other myxozoans in water samples have been developed for Ceratonova shasta (Hallett \& Bartholomew 2006), Parvicapsula minibicornis (Foott et al. 2007), Henneguya ictaluri (Griffin et al. 2009), Ceratonova puntazzi (Alama-Bermejo et al. 2013) and Kudoa yasunagai (Ishimaru et al. 2014) (for review, see Fontes et al. 2015). The development of qPCR to enable molecular detection and quantification specific to $T$. bryosalmonae spores in water samples would help to avoid or reduce the labour-intensive approaches currently employed to ascertain the presence and abundance of $T$. bryosalmonae in water bodies.

The aims of this study were to: (1) Develop a novel T. bryosalmonae SYBR ${ }^{\circledR}$ Green qPCR assay; (2) Use the assay to quantify T. bryosalmonae spores in rivers with known PKD occurrence in southern England over time; (3) Determine how the detection and abundance of T. bryosalmonae spores are affected by sample location, sample volumes, time of sampling, and point-measurements of water temperature and flow. 
Materials and Methods

104

\section{Sampling sites}

The sites selected for this study are on the Rivers Avon and Itchen in Hampshire and the

River Dun in Berkshire. The rivers represent spring-fed chalk stream systems that harbour wild brown trout (Salmo trutta) populations in lowland habitats in southern England. The rivers also provision rainbow trout (Oncorhynchus mykiss) fish farms that sustain regular PKD outbreaks. The bryozoan, Fredericella sultana occurs abundantly in the rivers growing as dense stands of colonies attached to submerged roots of riparian alder and willow trees. Water was sampled for qPCR studies near three separate $F$. sultana populations that were known to be infected (Fontes 2015) (on three different tree root systems) in each river.

\section{Water sampling}

Water samples were collected every Monday for five weeks in the three rivers during the period when high numbers of spores were expected to be released from infected bryozoans (May-June) (Tops 2004). Sampling of the Rivers Avon and Dun commenced on 14/05/12 and of the River Itchen on 13/05/13. Water samples were collected from approximately $30 \mathrm{~cm}$ below the water surface and $1 \mathrm{~m}$ downstream from the tree root systems (see Figure 1). One 2L plastic bottle was filled downstream from each root system by submerging the bottle to collect incoming flow. The submerged bottle was oriented upstream and slowly moved from side to side to collect water across approximately a $1.5 \mathrm{~m}$ stretch of the river, perpendicular to the river bank. In addition to these 2L samples, a bucket was used to fill one 24L plastic container with water collected $1 \mathrm{~m}$ downstream from the most downstream of the three roots in each river (Figure 1). Hence, for each sampling point a total of four water samples were taken in each river: three 2L samples at each root and one 24L sample at the most downstream root. At each sampling date, point-measurements of water temperature and water flow (mean velocity over 60 s, using an electromagnetic open channel flow meter (Model 8008/801, Valeport Ltd., Totnes, UK) were noted at each root. The samples were stored at $4^{\circ} \mathrm{C}$ in the original collection containers and filtered within $24 \mathrm{~h}$ of collection.

\section{Water filtration and DNA extraction}


The 24L samples were pre-filtered through a $30 \mu \mathrm{m}$ mesh in the field as the containers were filled. All samples were then filtered in the laboratory onto cellulose nitrate filter membranes (3 $\mu \mathrm{m}$ pore size, $142 \mathrm{~mm}$ diameter; Sartorius Stedim Biotech GmbH, Goettingen, Germany) at 1 bar using a pressure filtration system (Sartorius Stedim Biotech GmbH, Goettingen, Germany). Filter papers were scraped with a razor blade and the scrapings placed in a $1.5 \mathrm{ml}$ micro-centrifuge tube and stored at $-80^{\circ} \mathrm{C}$. The filtration system was rinsed thoroughly with deionised water and razor blades were sterilised using $\mathrm{EtOH}$ before processing each sample. Samples were freeze-dried at $-56^{\circ} \mathrm{C}$ to remove excess water and DNA was extracted using an UltraClean ${ }^{\circledR}$ Soil DNA kit (MO BIO Laboratories Inc., Carlsbad, California, USA). The 50 $\mu \mathrm{L}$ eluted DNA was then preserved at $-20^{\circ} \mathrm{C}$ and defrosted temporarily for screens.

\section{qPCR standards}

A 244 bp fragment of the T. bryosalmonae small subunit rDNA (SSU rDNA) gene was amplified from a genomic DNA sample derived from 85 mature spores obtained from sacs dissected from field collected colonies (from the River Avon) using the specific primers, 514F_new (5’ATTCAGGTCCATTCGTGAGTAACAAGC-3’) (Hartikainen et al. 2013) and 776R (5'-GCTGATACACCCAATTAAGGGCAG-3') (Morris et al. 2002). The resulting PCR product was purified and concentration measured using a Thermo Scientific NanoDrop 8000 Spectrophotometer (in $\mathrm{ng} / \mu \mathrm{l}$ ), adjusting it to $1 \mathrm{nM}$ in $1 \mathrm{ml}$ of TE buffer based on the mean molecular weight of a base pair (i.e. $660 \mathrm{Da}$ ). A 1:10 serial dilution of the standardised $1 \mathrm{nM}$ solution was performed and used as a template for the qPCR standard curve $(\mathrm{n}=7$ concentrations) with the primers described below (518F_Q and 680R_Q nest completely within 514F_new and 776R). The seven standards used encompassed the full range of samples tested. All quantification cycle $\left(C_{q}\right)$ values were determined using a fixed threshold normalised fluorescence of 0.1 (obtained manually) across all runs. The standard curve was applied to all runs using the first standard (1e-12 mol/L) to normalise each respective run.

\section{qPCR assay}

To detect and quantify T. bryosalmonae SSU rDNA, a SYBR ${ }^{\circledR}$ Green qPCR assay was developed, using species specific primers 518F_Q (5'- CAGGTCCATTCGTGAGTAACAA3’) and 680R_Q (5'- TGCCTCCTTAGTTAGGTAGACAAA-3' (Sigma-Aldrich ${ }^{\circledR}$, Poole, UK; primers were purified using the desalted method) and targeting a $182 \mathrm{bp}$ fragment of the T. bryosalmonae SSU rRNA gene. Primers were designed based on inspection of 
comprehensive alignment of all known malacosporean 18S SSU rDNA sequences. Dimer formation and primer quality were checked using NetPrimer (http://www.premierbiosoft.com/netprimer/) and via blast searches against the NCBI GenBank database (http://www.ncbi.nlm.nih.gov/genbank/). Primers developed for the assay target a portion of the SSU rRNA gene, which is present in the parasite genome as a tandem repeat unit. Focussing on multi-copy genes provides an advantage over single-copy genes in terms of detection sensitivities. Furthermore, as the number of tandem copies is approximately the same in each cell, SSU rDNA avoids potential biases associated with mitochondrial targets, which, although present in multiple copies, may vary in number depending on developmental stage, cell type and physiological state. The final volume of the qPCR mix was $10 \mu \mathrm{L}$ that was comprised of: $1 \mu \mathrm{L}$ of template DNA, 1x of Rotor-Gene SYBR $^{\circledR}$ Green PCR Master Mix (QIAGEN GmbH, Hilden, Germany), $1 \mu \mathrm{M}$ of each primer and molecular grade water (Fisher Scientific). The relative concentration of each primer was optimised in a test of nine combinations from $0.05-1 \mu \mathrm{L}$ of either forward or reverse primer. The optimal combination was $1 \mu \mathrm{L}$ of each primer as this was the one that produced the lowest $C_{q}$ value and the highest fluorescence (see Online Table 1). A CAS-1200 ${ }^{\mathrm{TM}}$ pipetting robot (Corbett Life Science, Mortlake, Australia) was used to prepare and dispense the master mix and template DNA into $0.2 \mathrm{ml}$ clear PCR tube strips (QIAGEN GmbH, Hilden, Germany). Each qPCR run included the following (in duplicate): (1) Negative control (water only); (2) Positive control (gDNA from a single T. bryosalmonae spore released from a bryozoan host); (3) Water samples to be tested; and (4) Seven qPCR standards (1e-12 to 1e$18 \mathrm{~mol} / \mathrm{L}$ ). A sample would only be considered to be positive if both duplicate reactions were positive. Reactions were performed in a Rotor-Gene ${ }^{\mathrm{TM}} 6000$ real-time PCR machine (Corbett Life Science, Mortlake, Australia) and runs analysed using the Rotor-Gene ${ }^{\mathrm{TM}} 6000$ Series Software 1.7 (Corbett Life Science, Mortlake, Australia). The thermal cycling conditions were: $95^{\circ} \mathrm{C}$ for $5 \mathrm{~min}$, followed by 45 cycles of: denaturation at $95^{\circ} \mathrm{C}$ for $5 \mathrm{~s}$; and annealing/extension at $60^{\circ} \mathrm{C}$ for $10 \mathrm{~s}$ (as recommended by QIAGEN for SYBR green assays). Data were acquired at the end of each cycle on the green dye channel (470 $\pm 10 \mathrm{~nm}$ excitation, $510 \pm 5 \mathrm{~nm}$ detection, 9.67 gain). A melting curve between $74-95^{\circ} \mathrm{C}$ was run at the end of each qPCR run. Water samples without a fluorescent signal were re-tested alongside negative and positive control samples. Intra-assay variability (repeatability) was calculated as the coefficient of variation (CV) for concentration variance (standard deviation [SD]) of seven standards and all eDNA samples. Inter-assay variability (reproducibility) was 
calculated as the $\mathrm{CV}$ of concentrations of each of the seven standards between four runs. All runs were performed by the same operator.

\section{qPCR assay sensitivity and specificity}

To test the sensitivity of the assay, serial dilutions $(1: 10-1: 100,000)$ of two positive and three negative (undiluted; used as controls) river water samples were analysed. We considered the limit of detection (LOD) of the assay to be at the highest $\mathrm{C}_{\mathrm{q}}$ value after which there was no fluorescence detected in dilutions of positive samples (Francois et al. 2003, Hallett \& Bartholomew 2006). This definition of LOD is conservative for detection, as it minimises the chances of false positives.

To test that the primers used were specific for T. bryosalmonae, we undertook qPCR analysis using the following range of templates: other malacosporean samples (Buddenbrockia allmani; B. plumatellae; Buddenbrockia species 2 and novel lineages 1-3 (Hartikainen et al. 2014); T. bryosalmonae sacs and respective spores; Fredericella sultana colonies not infected by T. bryosalmonae; F. sultana colonies with covert and overt T. bryosalmonae infections; uninfected and T. bryosalmonae-infected rainbow trout kidney tissue, the latter showing clinical signs of PKD. qPCR products of samples exhibiting a fluorescent signal were verified by direct sequencing on an ABI PRISM ${ }^{\circledR} 3700 x 1$ DNA analyser (Applied Biosystems ${ }^{\mathrm{TM}}$, Foster City, USA) using BigDye v1.1 chemistry.

\section{Inhibition testing}

To assess the presence of PCR inhibitors, qPCR amplification of an internal positive control (IPC) was compared in reactions containing eDNA extract to those only containing DNA-free water (Sigma-Aldrich ${ }^{\circledR}$, Poole, UK). This test was carried out for a subset of samples (Online Table 2). A total of seven river water samples ( $3 \times 24 \mathrm{~L}$ and $4 \times 2 \mathrm{~L}$ ) were randomly selected for this test. A synthetic IPC template was designed (5'-

GTATTCCTGGTTCTGTAGGTTGAGCGTAAAACGACGGCCAGTGAATTGTAATACG ACATGGTCATAGCTGTTTCCCGATACGGAAGTCCAGTCACAT -3’) (Microsynth AG; $97 \mathrm{bp}$, purified using the desalted method), inluding two priming sites with no known homology to published sequence data. The IPC template concentration was adjusted to $1 \mathrm{nM}$ (using Qubit ${ }^{\circledR} 2.0$ Fluorometer) and stored in TE buffer. A serial dilution (1:10) of the standardised solution was performed and the standard 1e-14 mol/L used as the IPC in a qPCR 
assay with primers MIMf (5’- GTATTCCTGGTTCTGTAGGTTGAGC -3') and MIMr (5'ATGTGACTGGACTTCCGTATCG -3’). A QIAgility pipetting robot (QIAGEN GmbH, Hilden, Germany) was used to prepare and dispense the master mix and template DNA, as well as the eDNA sample potentially containing the inhibitors. Each reaction containing IPC and eDNA sample was run in duplicate. In control reactions the eDNA was replaced with DNA-free water and ran as six replicates. Total reaction volume was $10 \mu \mathrm{L}$ containing: 1e-15 $\mathrm{mol} / \mathrm{L}$ of IPC, $1 \mu \mathrm{L}$ of a river water sample or DNA-free water, 1x SYBR® Select Master Mix (Applied Biosystems ${ }^{\mathrm{TM}}$, Foster City, USA) and $0.4 \mu \mathrm{M}$ of each primer (MIMf and $\mathrm{MIMr}$ ). The thermal cycling conditions were as follows: $50^{\circ} \mathrm{C}$ for $2 \mathrm{~min} ; 95^{\circ} \mathrm{C}$ for $2 \mathrm{~min}$; and 40 cycles of denaturation at $95^{\circ} \mathrm{C}$ for $15 \mathrm{~s}$ and annealing/extension at $60^{\circ} \mathrm{C}$ for $1 \mathrm{~min}$. This test was run on a 7500 Fast Real-Time PCR System (Applied Biosystems ${ }^{\mathrm{TM}}$, Foster City, USA) using a standard ramp speed and analysed using the 7500 Software version 2.0.6 (Applied Biosystems ${ }^{\mathrm{TM}}$, Foster City, USA). $\mathrm{C}_{\mathrm{q}}$ values were determined using a fluorescence threshold of 0.1 (obtained manually). Significant inhibition in a sample was defined as a difference of $>$ three cycles between mean $C_{q}$ values of IPC reactions with and without eDNA (Hartman et al. 2005). In such cases, samples were not used for further analyses as results of the $T$. bryosalmonae assay may appear biased due to inhibition. In addition to this test, the serial dilutions of the river water samples used in the sensitivity test were run with and without the inclusion of bovine serum albumin (BSA; $250 \mathrm{ng} / \mu \mathrm{L}$ final concentration) in the master mix.

\section{Estimating rDNA content of malacospores from bryozoans}

To estimate the number of $T$. bryosalmonae spores present in river water samples, we used forceps and a needle to release bryozoan malacospores from a sac. Spores were then rinsed in deionised water and individually pipetted, using a micro-injector (at 100-400 x magnification), into $1.5 \mathrm{ml}$ micro-centrifuge tubes and stored at $-80^{\circ} \mathrm{C}$. DNA from each spore was extracted using a DNeasy ${ }^{\circledR}$ Blood \& Tissue kit (QIAGEN GmbH, Hilden, Germany), eluted in $200 \mu \mathrm{L}$ TE buffer, and quantified using the qPCR protocol described above for water samples. Six individually extracted spores were used to estimate the SSU rDNA content of a single mature malacospore obtained from a bryozoan host. No malacospores from fish were available.

\section{Statistical analysis}


All statistical analyses were performed using R (version 2.15.1) (R Core Team 2014). Welch two sample t-tests were used to test differences in $\mathrm{C}_{\mathrm{q}}$ values assessed in: 1) IPC reactions spiked with and without river water; and 2) IPC reactions spiked with $2 \mathrm{~L}$ and $24 \mathrm{~L}$ river water samples. Parasite presence and abundance in river water samples was related to potential explanatory variables (sampling type (2L or 24L); point-measurements of water temperature; and water flow) using Generalised Linear Mixed Models (GLMMs) following the methods described in Zuur et al. (2009). The lme4 package (version 1.1-7) was used to analyse the parasite presence/absence data, assuming a binomial error distribution (Bates et al. 2013). For parasite abundance, the nlme package (version 3.1-117 was used, assuming a Gaussian error distribution (Pinheiro et al. 2014). Random effects models with no fixed factors were used to determine the optimal random effects structure using restricted maximum likelihood estimation (REML, parasite presence) or maximum likelihood estimation (ML, parasite abundance). Univariate analyses were then performed on each explanatory variable and those with P-values below 0.25 were included in a maximal model using ML following a visual check to remove any covariates that were strongly correlated. Non-significant variables and interactions were eliminated in a stepwise fashion, removing the least significant relationships first until only variables significant at $\mathrm{P}<0.05$ remained. Random intercept and slope models with intercept values of the significant fixed effects were evaluated and only retained if they led to a significant reduction in a model's log-likelihood.

\section{Results}

\section{qPCR sensitivity and specificity testing}

The linear standard curve (Online Figure 1) had a slope of -3.37, a correlation coefficient $\left(\mathrm{R}^{2}\right)$ of 0.998 and an amplification efficiency of $98 \%$. Although this standard curve was applied to all the runs using the first standard as a reference, the standards curves included in each run performed well with efficiency being higher than $96 \%$ and an $\mathrm{R}^{2}$ ranging from $0.989-0.999$. The dilution series of two known positive samples (both replicates fluorescing) indicated that the fluorescence signal was lost at an approximate mean $C_{q}$ value of 31.01 and 27.46 in each qPCR-positive water sample (Figure 2 and Online Table 3). This suggests that the LOD for this assay is $31 \mathrm{C}_{\mathrm{q}}$ as this was the highest value obtained for the two positive samples. The mean concentration of parasite rDNA in a bryozoan malacospore, based on six individual spores, was $1.96 \mathrm{e}-18 \mathrm{~mol} / \mathrm{L}\left( \pm 1.69 \mathrm{e}-19 \mathrm{SD}\right.$ ) (i.e. $25.83 \mathrm{C}_{\mathrm{q}}$ ) in $200 \mu \mathrm{L}$, which equates roughly 
to 0.005 spores per qPCR reaction based on a reaction volume of $10 \mu \mathrm{L}$. A value of $31 \mathrm{C}_{\mathrm{q}}$ equates to 0.089 spores in $50 \mu \mathrm{L}$ of eluted DNA $(1.75 \mathrm{e}-19 \mathrm{~mol} / \mathrm{L}$ - calculated using the standard curve equation presented in Online Figure $\left.1\left[C_{q}=10^{\wedge}(-0.297 * 31-9.551)\right]\right)$ or 0.0018 spores per qPCR reaction (spore numbers calculated based on the concentration of 1 spore [1.96e-18 mol/L]). Samples that were negative when undiluted did not exhibit any fluorescence at any dilution (see Figure 2).

Melting curves produced two peaks. The first was at $\sim 77.3^{\circ} \mathrm{C}$, corresponding to the presence of primer dimer. The second peak, at $\sim 84.5^{\circ} \mathrm{C}$, corresponded to amplification of the target template. Negative samples and controls produced the first peak, in positive samples only the second peak was present. Although an LOD of $31 \mathrm{C}_{\mathrm{q}}$ was implied by the sensitivity analysis, samples with a sub-LOD concentration were found in $22 \%$ of the river samples $(n=60)$, with $\mathrm{C}_{\mathrm{q}}$ values up to 34.5 (corresponding to 0.015 spores in $50 \mu \mathrm{L}$ of eluted DNA (2.96e-20 $\mathrm{mol} / \mathrm{L}$ ) or 0.0003 spores per qPCR reaction). Differences between the sensitivity analysis and the tested samples suggest that a $C_{q}$ of 31 is the limit of quantification (LOQ) which, for complex samples, is generally 5 - 10 times higher than the absolute LOD (Berdal \& HolstJensen 2001). The assay exhibited both low to high repeatability and high reproducibility. The former is supported by substantial variation in intra-assay variance for eDNA samples (CV range $=3.21-74.70 \%)$ and a low intra-assay variance for standards (CV range $=0.08$ 39.24\%). The latter is supported by the small inter-assay variance for the concentrations of all seven standards (CV range $=5.28-10.03 \%$; see Online Table 4$)$. Therefore, we set the LOQ in the qPCR assay at $31 \mathrm{C}_{\mathrm{q}}$, which is six times the concentration of the absolute LOD (34.5 $\mathrm{C}_{\mathrm{q}}$ ). For statistical analyses, the LOQ was used as the cut-off for parasite presence and abundance.

The qPCR assay was highly specific to the presence of $T$. bryosalmonae. No amplification was observed in negative samples (i.e. uninfected F. sultana colony, uninfected rainbow trout kidney and Buddenbrockia samples) and all amplified products were verified by sequence analysis as belonging to $T$. bryosalmonae. The $\mathrm{C}_{\mathrm{q}}$ results for $T$. bryosalmonae were as follows: one bryozoan malacospore (mean $=27.45, \mathrm{SD}=0.08, \mathrm{n}=6$ ); and sacs with an unknown number of spores at potentially different developmental stages (mean $=10.43$, SD = 0.37). Infected host material produced the following $C_{q}$ results: overtly infected colony 
(mean $=15.34, \mathrm{SD}=0.31)$; covertly infected colony (mean =24.13, SD = 0.11); and PKDaffected rainbow trout kidney $($ mean $=18.35$, $\mathrm{SD}=0.00)$.

\section{Inhibition testing}

334

335

A significant increase in $\mathrm{C}_{\mathrm{q}}$ values during IPC amplification was observed when river water was added to reactions (Welch Two Sample t-test: $\mathrm{t}=2.942$, d.f. $=8.595, \mathrm{P}=0.017$ ), indicating the presence of PCR inhibition. Spiking of an IPC reaction with river water samples (Online Table 2$)$ increased $C_{q}$ values on average by $1.112\left(C_{q}\right.$ with river water, mean $=17.452, \mathrm{SD}=0.341, \mathrm{n}=7 ; \mathrm{C}_{\mathrm{q}}$ without river water: mean $=16.340, \mathrm{SD}=0.166, \mathrm{n}=$ 6). As differences were lower than three cycles all samples were used in the subsequent analyses. Apparent effects of inhibition were larger in 2L than 24L samples, with significantly higher $\mathrm{C}_{\mathrm{q}}$ values in $2 \mathrm{~L}$ samples (mean $=18.005, \mathrm{SD}=0.814, \mathrm{n}=4$ ) than in $24 \mathrm{~L}$ samples $($ mean $=16.715, \mathrm{SD}=0.152, \mathrm{n}=3$ ) (Welch Two Sample t-test: $\mathrm{t}=3.102$, d.f. $=$ 3.279, $\mathrm{P}=0.047$ ). The standard deviation between replicates of all IPC reactions was small (mean $=0.219, \mathrm{SD}=0.188, \mathrm{n}=8$ ) and the dissociation melting curves of positive reactions produced a sharp peak at $\sim 79^{\circ} \mathrm{C}$. The addition of BSA to PCR reactions did not improve amplification success (see Online Table 3).

\section{Parasite presence and abundance in river water}

A total of 60 water samples (20 for each river) were collected ( $15 \times 2 \mathrm{~L}$ samples and $5 \times 24 \mathrm{~L}$ samples per river). The mean temperature of five point measurements was not significantly different between the Rivers Dun and Itchen, although it differed significantly between the Rivers Avon and Itchen and between the Rivers Avon and Dun (see Table 1). Hence, the River Avon was the warmest of the three rivers during the sampling period. Pointmeasurements of water temperatures in the River Itchen remained lower and more stable $\left(10.5-12.6^{\circ} \mathrm{C}\right)$ throughout the study than in the other two rivers (Avon: $12.0-18.4^{\circ} \mathrm{C}$, Dun: $10.5-15.9^{\circ} \mathrm{C}$ ), where temperatures peaked in the third week (Figure 3a-c). Temperature did not vary significantly between roots within a river, although water flow did (see Table 1), particularly in the River Avon (see Figure 3a-c). There was no clear link between water flow and temperature, the exception being in the River Avon when both environmental variables peaked in the third week. 
362 Almost half of the samples tested positive for T. bryosalmonae (40\%). T. bryosalmonae was detected in water samples taken each week in the Rivers Avon and Dun, but was only detected in the River Itchen samples collected during the last two weeks of sampling (Figure 4). Parasite DNA was rarely detected in all samples from a given river on a given date. The overall proportion of positive samples was higher in the River Avon (60\%), than in the Rivers Dun (40\%) and Itchen (20\%). The presence of T. bryosalmonae in water samples was predominantly influenced by the individual rivers, root systems, and sampling dates. These factors were subsequently included as random effects in mixed models to assess the significance of fixed explanatory variables (sample volume, flow and point-measurements of water temperature). Parasite DNA was detected more often using the 24L than 2L sampling method. The 2L samples were 0.11 times (odds ratio) less likely to contain T. bryosalmonae than 24L samples acquired on the same date. A total of $29 \%$ and $73 \%$ of $2 \mathrm{~L}$ and $24 \mathrm{~L}$ samples, respectively, were positive. Temperature also had an effect on the presence of $T$. bryosalmonae in the river water, with a unit increase in temperature increasing the likelihood of presence by 1.60 times (odds ratio) (see Table 1).

$\mathrm{C}_{\mathrm{q}}$ values in the river water samples were very close to the LOD, particularly those of $2 \mathrm{~L}$ samples $\left(\right.$ mean $=29.498, \mathrm{SD}=1.332, \mathrm{n}=13$ ). Although not significant, $\mathrm{C}_{\mathrm{q}}$ values decreased and variation increased slightly in the $24 \mathrm{~L}$ samples (mean $=28.989, \mathrm{SD}=1.355, \mathrm{n}=11$ ). Sampling date explained most of the variation in $\mathrm{C}_{\mathrm{q}}$ values and none of the explanatory variables were significantly associated with $C_{q}$ values (see Table 1).

The estimated numbers of spores (converted from the template concentrations) ranged from 0.15-3.56 in the 2L sampling method (mean $=0.623, \mathrm{SD}=0.912, \mathrm{n}=13$ ) and from 0.19-4.46 in the $24 \mathrm{~L}$ sampling method (mean $=0.894, \mathrm{SD}=1.214, \mathrm{n}=11$ ) (Figure 4 and Online Table 5 for the corresponding $C_{q}$ values). Both methods detected up to 4 spores per water sample but most positive samples using both methods contained less than one spore. In the River Avon, T. bryosalmonae was more likely to be present in water sampled near the root system furthest downstream, but no detectable pattern in spore detection relative to root systems was found in the Rivers Dun and the Itchen (Online Table 5). The lower detection frequency in the River Itchen was notable and was possibly associated with lower temperatures in this river. Although not significant (see Table 1), spore numbers and variation in spore numbers 
increased slightly in the 24L samples relative to the 2L samples. Sampling date explained most of the variation in spore number.

\section{Discussion}

\section{A new qPCR assay for $\mathrm{T}$. bryosalmonae}

The novel T. bryosalmonae SYBR ${ }^{\circledR}$ Green qPCR assay to detect and quantify spores in water samples performed consistently in three river systems over space and time. The LOD of the assay was $34.5 \mathrm{C}_{\mathrm{q}}$ and the LOQ was $31 \mathrm{C}_{\mathrm{q}}$, corresponding to 0.0003 and 0.0018 spores per qPCR reaction, respectively. The assay was both sensitive and reliable, quantifying the estimated SSU rDNA content of 0.005 spores consistently in six biological replicates (mean $=25.83, \mathrm{SD}=1.24)$. The number of spores detected by the $2 \mathrm{~L}$ sampling method ranged from approximately 0.05 to 3.56 and by the $24 \mathrm{~L}$ method from 0.02 to 4.46 spores. We suggest that reasons why the larger samples did not detect more spores include patchiness of spores and lack of replication within sites of large volume samples. We provide below further discussion on how inhibition and spore quantification methods may affect our estimates.

\section{Inhibition testing}

Detection of pathogens in natural water samples can be severely limited by PCR inhibition due to substances such as calcium and humic acids (Opel et al. 2010). We developed an IPC molecule and associated primers which can be used to test for the presence of inhibition in reactions run alongside the quantification reactions. Although the $\mathrm{C}_{\mathrm{q}}$ values increased significantly when river water was added, the effect size was deemed to be low (1.112 cycles). Hartman et al. (2005) only consider a shift in $C_{q}$ values of $\geq$ three cycles as a sign of inhibition. In our case no 24L samples showed significant inhibition, whereas 2L samples from the Rivers Dun and Avon (but not Itchen) showed signals of low level inhibition. This result is unexpected as large volume samples would be expected to suffer more from accumulation of inhibitory compounds. In this study, the processing of the $2 \mathrm{~L}$ and $24 \mathrm{~L}$ samples differed by pre-filtration through a $30 \mu \mathrm{m}$ mesh, which was only applied to the $24 \mathrm{~L}$ samples. It remains untested whether this may have removed particles carrying inhibitor compounds and could explain the lower inhibition signal in the 24L samples. It should be noted that these results are based on a low number of samples and thus interpreting patterns between sample volumes is difficult. Nevertheless, the results underlie the conclusion that the 
effects of inhibition in our samples are likely negligible. Also, no improvement to the final workflow was seen following the dilution of river water samples, nor by the addition of BSA, suggesting that the inhibition present in our river water samples is minimal as shifts of one cycle can occur between runs and instruments. We recommend that an IPC is always included to monitor the presence of inhibition in eDNA samples and may even be multiplexed into sample assays on platforms allowing fluorescence detection on multiple channels.

\section{Detecting and quantifying $\mathbf{T}$. bryosalmonae spores in river water}

T. bryosalmonae was detected in at least one water sample on all sampling dates in the Rivers Dun and Avon but was not detected in the River Itchen until the fourth sampling date. Estimated spore numbers were consistently low. The presence of T. bryosalmonae in water samples was predominantly influenced by individual rivers, roots within rivers, and sampling dates. However, despite the potential confounding effects of such spatial and temporal variation, we were able to gain some insights into factors that may influence spore presence and abundance. For example, we found that sampling date explained most of the variation in spore number with few or no spores being detected in the early sampling periods in both $2 \mathrm{~L}$ and 24L samples from each river. In addition, we found that T. bryosalmonae was 1.6 times more likely to be detected by qPCR given a unit increase in temperature - a result in keeping with temperature-induced development and release of spores from bryozoans (see Tops \& Okamura 2003, Tops et al. 2006). However, it should be noted that the water temperature measurements were only taken once a week rather than continuously. Although water flow was found to be highly variable amongst rivers and roots, we found no effect of flow on the detection or quantification of parasite spores. Foott et al. (2007) similarly found water flow to have no influence on the detection of spores of the myxozoans $C$. shasta and P. minibicornis in the Klamath River in California

It should be noted that malacospores released from bryozoans and fish differ in the number of constituent cells. Furthermore, it is likely that these cells vary in ploidy levels. On the basis of cell number, the rDNA content of fish malacospores may be estimated as $\leq 50 \%$ than that of bryozoan malacospores. However, fish malacospores are diploid while at least a proportion or perhaps all of the cells in bryozoan malacospores are haploid (see Canning et al. 2007 for discussion of ploidy of cells comprising bryozoan malacospores). Until both ploidy levels of 
cells and cell numbers of malacospores are fully understood, our approach provides a direct estimate of bryozoan malacospore concentrations but an underestimate of fish malacospore concentrations. Ignoring unrelated copy number variation between spore states and cells and applying the most conservative scenario based on known and proposed states (i.e. diploidy of all fish malacospore cells and no secondary cell within the sporoplasm [Morris \& Adams 2008] and diploidy of all bryozoan malacospore cells apart from haploid sporoplasms which, however, do contain an internal haploid secondary cell [Canning et al. 2007]), the rDNA content of fish malacospores would be some $46.7 \%$ less than those of bryozoan malacospores. Thus fish malacospore rDNA concentrations would be underestimated by approximately $100 \%$.

A consideration of the dominant spore type in our samples is important given the above variation in genomic DNA content of spores. Although timing of spore release from fish hosts is unknown, spores are released in low numbers in fish urine (Hedrick et al. 2004) and will be greatly diluted. It is therefore unlikely that spores deriving from fish substantially contributed to the patterns detected here, particularly as we collected water directly downstream from bryozoan populations known to sustain infections of T. bryosalmonae.

The 24L sampling method was more efficient than the 2L sampling method at detecting $T$. bryosalmonae with detection more likely for the larger volume samples taken on the same dates and at the same root systems. However, the numbers of spores estimated by qPCR for 2L and 24L samples were comparable (from 0.15 - 4.5). Detection of parasite DNA was expected on all sampling dates based on our knowledge of spore development in bryozoans in the field sites under investigation and results of previous studies quantifying myxozoans in 2L water samples by qPCR (Hallett \& Bartholomew 2006). This was generally the case for samples from the Rivers Dun and Avon, although not always for all samples on each date. Lack of detection in some replicate samples is likely to represent false negatives due to failure to detect or to capture spores in the samples. Since the assay was shown to be highly sensitive and inhibition was low, the latter seems the most likely explanation - a premise supported by the generally low spore concentrations in each river. The lower incidence of false negatives in the two rivers with the $24 \mathrm{~L}$ sampling technique $(10 \% ; n=10)$ when compared to the $2 \mathrm{~L}$ method $(63 \% ; n=30)$ provides additional support for this inference. However, the consistent lack of detection of T. bryosalmonae in qPCR assays on River Itchen 
water collected during the first three weeks suggests true absence during this period, possibly reflecting temperatures that remained relatively low on this river.

Although limited in being only a rough estimation, parasite abundance was not significantly higher in the large volume samples. This is consistent with previous evidence (the high proportion of false negative samples for $2 \mathrm{~L}$ samples and qPCR readings close to the LOD) that spore concentrations in the rivers were low at the time of sampling. However, different DNA extraction methods were used for spore samples and river water samples and this may affect the accuracy of our estimates. The handling of the spores collected in the laboratory and those collected as parts of eDNA samples also differed, e.g. the spores from the environment always underwent a filtration procedure which was not the case for laboratory collected spores. This may have further biased the yield of DNA and potentially results in an underestimate of spore numbers deriving from eDNA samples. Sample types should undergo similar treatments in future studies to ensure parallel conversions to spore numbers. Moreover, the fragile nature of malacosporean spores may result in lysis during water filtration and subsequent loss of DNA through the fixed-pore size membranes. Use of glass fibre filters may guard against the latter scenario, as such filters are known to bind free DNA (Nygaard \& Hall 1963). Certainly, the abundances of T. bryosalmonae inferred by qPCR were much lower than those estimated in similar studies on myxosporean myxozoans. These contrasting abundances may be explained by the more robust nature and greater longevity of spores produced by myxosporeans relative to those of malacosporeans. For example, Hallett \& Bartholomew (2006) detected 1 - 20 spores/L of the myxosporean, C. shasta, in river water and Griffin et al. (2009) detected 37 - 249 spores/L of the myxosporean, H. ictaluri, in pond water. On the other hand, Alama-Bermejo et al. (2013) only detected up to 1 spore of the myxosporean Ceratonova puntazzi in 8L of sea water. It is possible that spore abundances of some myxozoans are naturally low. Further investigation is, however, required as we sampled water over a relatively short period of time, at a similar time each day, and did not simultaneously sample bryozoan populations to ascertain spore production.

\section{Caveats and recommendations for future studies}

The primers developed for the assay were verified to be specific to the genus Tetracapsuloides. Alignments with other putative Tetracapsuloides species (BartošováSojková et al. 2014) were inspected, but no DNA isolates were available for testing with the 
primers developed in this study. Since the primers contain 3 - 6 mismatches to the most closely related Tetracapsuloides species (Bartošová-Sojková et al. 2014), they may also amplify SSU rDNA from these species, especially in the absence of the specific target. Therefore, in environments where the fish fauna is diverse, we recommend post-qPCR sequencing to further verify results. We also recommend examining the melting curve to distinguish between true and false positive samples. Melting curves should produce a sharp peak at $\sim 84.5^{\circ} \mathrm{C}$ for true positive samples while false positive samples will only amplify primer dimer with a wide peak at $\sim 77.3^{\circ} \mathrm{C}$. However, some variation in the template peak temperature, due to either minor pipetting error or nucleotide differences when analysing samples potentially containing different $T$. bryosalmonae strains, should be taken into consideration.

A potential limitation in the use of environmentally derived DNA to study parasites with multiple host life-cycles is the inability to distinguish between parasite stages released from different hosts. For example, T. bryosalmonae DNA detected in our water samples could have four potential sources: (1) Spores that developed and matured in bryozoans; (2) Spores originating from salmonids; (3) Fragments of infected bryozoan colonies present in the water samples; (4) Loose, non-cell associated DNA. Filter papers were closely examined after filtration and no colonies were ever observed. Trapping of loose DNA on fixed cellulose acetate filters is possible as filter papers progressively clog during processing, but this type of filter should predominantly retain only larger particles. Therefore, most of the signal for $T$. bryosalmonae is likely to be attributed to spores that were released from bryozoan hosts, particularly since sampling was conducted directly downstream from known infected bryozoan populations and when spore production was expected to be relatively high (Fontes pers. obs). Further work is required to characterise temporal variation in abundances of sporogonic stages in renal tubules of wild fish and the spore loads that are shed from fish.

There are many potential processes that may impede eDNA-based detection and absolute quantification. Examples include: (1) Loss of DNA if spores rupture during the filtration process; (2) Sample DNA degradation as a result of repetitive freezing/defrosting processes; (3) Short viability of T. bryosalmonae spores (i.e. 12 - 24 h; Feist et al. 2001, De Kinkelin et al. 2002); and (4) Low DNA extraction efficiency. These biases are largely unavoidable but their impact can be minimised by using appropriate standards, positive and negative controls, 
well-established and routine sampling methods and post-sampling processes that will enable relative and robust comparisons and maximise information gain. For instance, as mentioned above, lysis of DNA through fixed-pore size membranes could be avoided by using glass fibre filters that bind free DNA. In general, the main sources of uncertainty for water samplebased detection methods for parasites and pathogens stem from spatial and temporal variation in the distribution of target organisms, as we have found here. Repeated sampling, increased replication and larger sample volumes may be required to address these issues.

The assay developed here provides a tool to resolve parasite abundances over fine time scales and for longer periods. Such studies, for example, may detect seasonal peaks and troughs in the abundance of $T$. bryosalmonae, providing insights as to when transmission is generally achieved in the complex life cycle. Meanwhile, daily variation in estimated spore concentrations in water may provide evidence for spore release entrained to a circadian rhythm, coinciding with fish host activities and increased transmission success. Other applications of our assay include examining how $T$. bryosalmonae abundances change over environmental gradients, with the presence and absence of fish farms sustaining PKD outbreaks, and with hydrological connectivity in river networks.

\section{Conclusions}

We present the first eDNA-based protocol for the detection and quantification of $T$. bryosalmonae spores in freshwater samples. Our SYBR ${ }^{\circledR}$ Green qPCR assay combined with an IPC provides an easy and rapid method to detect and quantify $T$. bryosalmonae. We have used the assay to characterise variation in spore presence and provide an estimate of abundance in space and time in three river systems. Our new qPCR assay offers a nondestructive means of determining infection risk that may be used to complement traditional monitoring methods.

\section{Acknowledgements}

We are thankful to Darren Butterworth (Trafalgar Fisheries [River Avon]), Robert Starr (Hungerford Fishery [River Dun]), Mrs Pearse and Winchester College (River Itchen) for access to collecting sites. We would also like to thank all field assistants based at the Natural 
History Museum (Brian Smith, Laetitia Gunton, Alex Gruhl, Graihagh Hardinge, Jahcub Trew) and Nick Taylor (Centre for Environment, Fisheries \& Aquatic Sciences [Cefas]) and Chris Williams (Environment Agency [EA]) for their support for research on assessing the risk of PKD. We thank Sascha Hallett (Oregon State University) for initial advice on techniques. The research was funded by the Natural Environment Research Council (NE/019227/1), the EA and Cefas. IF was also funded by the Fundação para a Ciência e a Tecnologia (SFRH/BD/86118/2012) and Pescanova, SA. HH was funded by the Swiss National Science Foundation Sinergia project CRSII3_147649.

\section{References}

Alama-Bermejo G, Šíma R, Raga JA, Holzer AS (2013) Understanding myxozoan infection dynamics in the sea: seasonality and transmission of Ceratomyxa puntazzi. Int J Parasitol 43:771-780

Audemard C, Ragone Calvo LM, Paynter KT, Reece KS, Burreson EM (2006) Real-time PCR investigation of parasite ecology: in situ determination of oyster parasite Perkinsus marinus transmission dynamics in lower Chesapeake Bay. Parasitology 132:827-842

Bartošová-Sojková P, Hrabcová M, Pecková H, Patra S, Kodádková A, Jurajda P, Tyml T, Holzer AS (2014) Hidden diversity and evolutionary trends in malacosporean parasites (Cnidaria: Myxozoa) identified using molecular phylogenetics. Int J Parasitol 44:565577

Bates D, Maechler M, Bolker B, Walker S (2013) lme4: Linear mixed-effects models using Eigen and S4. Version: 1.0-4 [software package]

Berdal KG, Holst-Jensen A (2001) Roundup Ready ${ }^{\circledR}$ soybean event-specific real-time quantitative PCR assay and estimation of the practical detection and quantification limits in GMO analyses. Eur Food Res Technol 213:432-438

Bettge K, Wahli T, Segner H, Schmidt-Posthaus H (2009) Proliferative kidney disease in rainbow trout: time- and temperature-related renal pathology and parasite distribution. Dis Aquat Org 83:67-76

Canning EU, Curry A, Feist SW, Longshaw M, Okamura B (2000) A new class and order of myxozoans to accommodate parasites of bryozoans with ultrastructural observations on Tetracapsula bryosalmonae (PKX organism). J Eukaryot Microbiol 47:456-468 
Canning EU, Curry A, Hill SLL, Okamura B (2007) Ultrastructure of Buddenbrockia allmani n. sp.(Myxozoa, Malacosporea), a parasite of Lophopus crystallinus (Bryozoa, Phylactolaemata). J Eukaryot Microbiol 54:247-262

De Kinkelin P, Gay M, Forman S (2002) The persistence of infectivity of Tetracapsula bryosalmonae-infected water for rainbow trout, Oncorhynchus mykiss (Walbaum). J Fish Dis 25:477-482

Feist SW, Longshaw M, Canning EU, Okamura B (2001) Induction of proliferative kidney disease (PKD) in rainbow trout Oncorhynchus mykiss via the bryozoan Fredericella sultana infected with Tetracapsula bryosalmonae. Dis Aquat Org 45:61-68

Feist SW, Morris DJ, Alama-Bermejo G, Holzer AS (2015) Cellular processes in myxozoans. In: Okamura B, Gruhl A, Bartholomew JL (eds) Myxozoan evolution, ecology and development. Springer International Publishing, Cham, Switzerland

Ferguson HW, Needham EA (1978) Proliferative kidney disease in rainbow trout Salmo gairdneri Richardson. J Fish Dis 1:91-108

Fiala I, Bartošová-Sojková P, Okamura B, Hartikainen H (2015) Adaptive radiation and evolution within the Myxozoa. In: Okamura B, Gruhl A, Bartholomew JL (eds) Myxozoan evolution, ecology and development. Springer International Publishing, Cham, Switzerland

Fontes, I. (2015) Life history, distribution and invertebrate hostparasite interactions of the causative agent of proliferative kidney disease (PKD), Tetracapsuloides bryosalmonae. $\mathrm{PhD}$, University of Aberdeen, Aberdeen

Fontes I, Hallett S, TorAtle M (2015) Comparative epidemiology of myxozoan diseases. In: Okamura B, Gruhl A, Bartholomew JL (eds) Myxozoan evolution, ecology and development. Springer International Publishing, Cham, Switzerland

Foott JS, Stone R, Wiseman E, True K, Nichols K (2007) Longevity of Ceratomyxa shasta and Parvicapsula minibicornis Actinospore Infectivity in the Klamath River. J Aquat Anim Health 19:77-83

Francois P, Pittet D, Bento M, Pepey B, Vaudaux P, Lew D, Schrenzel J (2003) Rapid detection of methicillin-resistant Staphylococcus aureus directly from sterile or nonsterile clinical samples by a new molecular assay. J Clin Microbiol 41:254-260

Gay M, Okamura B, de Kinkelin P (2001) Evidence that infectious stages of Tetracapsula bryosalmonae for rainbow trout Oncorhynchus mykiss are present throughout the year. Dis Aquat Org 46:31-40 
Grabner DS, El-Matbouli M (2008) Transmission of Tetracapsuloides bryosalmonae (Myxozoa: Malacosporea) to Fredericella sultana (Bryozoa: Phylactolaemata) by various fish species. Dis Aquat Org 79:133-139

Grabner DS, El-Matbouli M (2009) Comparison of the susceptibility of brown trout (Salmo trutta) and four rainbow trout (Oncorhynchus mykiss) strains to the myxozoan Tetracapsuloides bryosalmonae, the causative agent of proliferative kidney disease (PKD). Vet Parasitol 165:200-206

Griffin MJ, Pote LM, Camus AC, Mauel MJ, Greenway TE, Wise DJ (2009) Application of a real-time PCR assay for the detection of Henneguya ictaluri in commercial channel catfish ponds. Dis Aquat Org 86:223-233

Guy RA, Payment P, Krull UJ, Horgen PA (2003) Real-time PCR for quantification of Giardia and Cryptosporidium in environmental water samples and sewage. Appl Environ Microbiol 69:5178-5185

Hallett SL, Bartholomew JL (2006) Application of a real-time PCR assay to detect and quantify the myxozoan parasite Ceratomyxa shasta in river water samples. Dis Aquat Org 71:109-118

Hartikainen H, Fontes I, Okamura B (2013). Parasitism and phenotypic change in colonial hosts. Parasitology 140:1403-1412

Hartman LJ, Coyne SR, Norwood DA (2005) Development of a novel internal positive control for Taqman ${ }^{\circledR}$ based assays. Mol Cell Probes 19:51-59

Hedrick RP, Baxa DV, De Kinkelin P, Okamura B (2004) Malacosporean-like spores in urine of rainbow trout react with antibody and DNA probes to Tetracapsuloides bryosalmonae. Parasitol Res 92:81-88

Hung YW, Remais J (2008) Quantitative detection of Schistosoma japonicum cercariae in water by real-time PCR. PLoS Negl Trop Dis 2:e337

Ishimaru K, Takumi M, Kazunobu T, Sho S (2014) Seasonal monitoring of Kudoa yasunagai from sea water and aquaculture water using quantitative PCR. Dis Aquat Org 108:4552

Kent ML, Hedrick RP (1986) Development of PKX myxosporean in rainbow trout Salmo gairdneri. Dis Aquat Org 1:169-182

Kumar G, Abd-Elfattah A, Saleh M, El-Matbouli M (2013) Fate of Tetracapsuloides bryosalmonae (Myxozoa) after infection of brown trout Salmo trutta and rainbow trout Oncorhynchus mykiss. Dis Aquat Org 107:9-18 
McGurk C, Morris DJ, Adams A (2005) Microscopic studies of the link between salmonid proliferative kidney disease (PKD) and bryozoans. Fish Vet J 62-71

Morris DC, Morris DC, Adams A (2002) Development of improved PCR to prevent false positives and false negatives in the detection of Tetracapsula bryosalmonae, the causative agent of proliferative kidney disease. J Fish Dis 25:483-490

Morris DJ, Adams A (2006) Transmission of Tetracapsuloides bryosalmonae (Myxozoa: Malacosporea), the causative organism of salmonid proliferative kidney disease, to the freshwater bryozoan Fredericella sultana. Parasitology 133:701-709

Morris DJ, Adams A (2008) Sporogony of Tetracapsuloides bryosalmonae in the brown trout Salmo trutta and the role of the tertiary cell during the vertebrate phase of myxozoan life cycles. Parasitology 135:1075-1092

Nygaard AP, Hall BD (1963) A method for the detection of RNA-DNA complexes. Biochem Biophys Res Commun 12:98-104

Okamura B, Feist SW (2011) Emerging diseases in freshwater systems. Freshwat Biol 56:627-637

Okamura B, Hartikainen H, Schmidt-Posthaus H, Wahli T (2011) Life cycle complexity, environmental change and the emerging status of salmonid proliferative kidney disease. Freshwat Biol 56:735-753

Opel KL, Chung D, McCord BR (2010) A study of PCR inhibition mechanisms using real time PCR. J Forensic Sci 55:25-33

Pinheiro J, Bates D, DebRoy S, Sarkar D, Team RC (2014) nlme: linear and nonlinear mixed effects models. Version: 3.1-117 [software package]

R Core Team (2014) R: A language and environment for statistical computing. In: R: A language and environment for statistical computing. R Foundation for Statistical Computing, Vienna, Austria

Strand DA, Jussila J, Johnsen SI, Viljamaa-Dirks S, Edsman L, Wiik-Nielsen J, Viljugrein H, Engdahl F, Vrålstad T (2014) Detection of crayfish plague spores in large freshwater systems. J Appl Ecol 51:544-553

Tops S (2004) Ecology, life history and diversity of malacosporeans. PhD, University of Reading, Reading

Tops S, Lockwood W, Okamura B (2006) Temperature-driven proliferation of Tetracapsuloides bryosalmonae in bryozoan hosts portends salmonid declines. Dis Aquat Org 70:227-236 
724 Tops S, Okamura B (2003) Infection of bryozoans by Tetracapsuloides bryosalmonae at sites endemic for salmonid proliferative kidney disease. Dis Aquat Org 57:221-226

726 Wahli T, Bernet D, Steiner PA, Schmidt-Posthaus H (2007) Geographic distribution of

727 Tetracapsuloides bryosalmonae infected fish in Swiss rivers: an update. Aquat Sci

728 69:3-10

729 Zuur AF, Ieno EN, Walker NJ, Saveliev AA, Smith GM (2009) Mixed effects models and extensions in ecology with R, Springer, New York 
732 Figure 1. Location of Roots 1-3 in the Rivers Avon (a), Dun (b) and Itchen (c) along with 733 ordnance survey grid references. Root 3 is in the most downstream position and was where 734 24L samples were taken. (source: OS Street View layer [TIFF geospatial data], Scale 735 1:10,000, Coverage: UK, Ordnance Survey (GB), Using: EDINA Digimap Ordnance Survey 736 Service, <http://digimap.edina.ac.uk/>, Downloaded: 20 April 2015, Updated: 26 September 737 2014. (C) Crown Copyright and Database Right [20/04/2015]. Maps composed in ESRI 738 ArcGIS 10.0.

Figure 2. Results from the Tetracapsuloides bryosalmonae sensitivity test of the qPCR assay. A 1:10 serial dilution of two positive samples (Positive sample 1 - Avon 24L, collected 742 downstream from root 3 in the fourth week; Positive sample 2 - Itchen 2L collected 743 downstream from root 3 in the fifth week). The mean quantification cycle $\left(\mathrm{C}_{\mathrm{q}}\right)$ values and the respective standard errors are presented for each dilution. Each sample was run in duplicate.

Figure 3. Water temperature and flow during the five week period in the Rivers Avon (a), Dun (b) and Itchen (c). Box plots for water flow and temperature include the interquartile range box, the median and the mean (black circles).

Figure 4. Boxplot of Tetracapsuloides bryosalmonae spore numbers as estimated by qPCR in $2 \mathrm{~L}$ water samples collected at three roots and one $24 \mathrm{~L}$ water sample collected at the most downstream root each week for a period of five weeks in the Rivers Avon, Dun and Itchen. Data for the 2L samples are averaged across the three roots. 
$754 \quad$ Figure 1
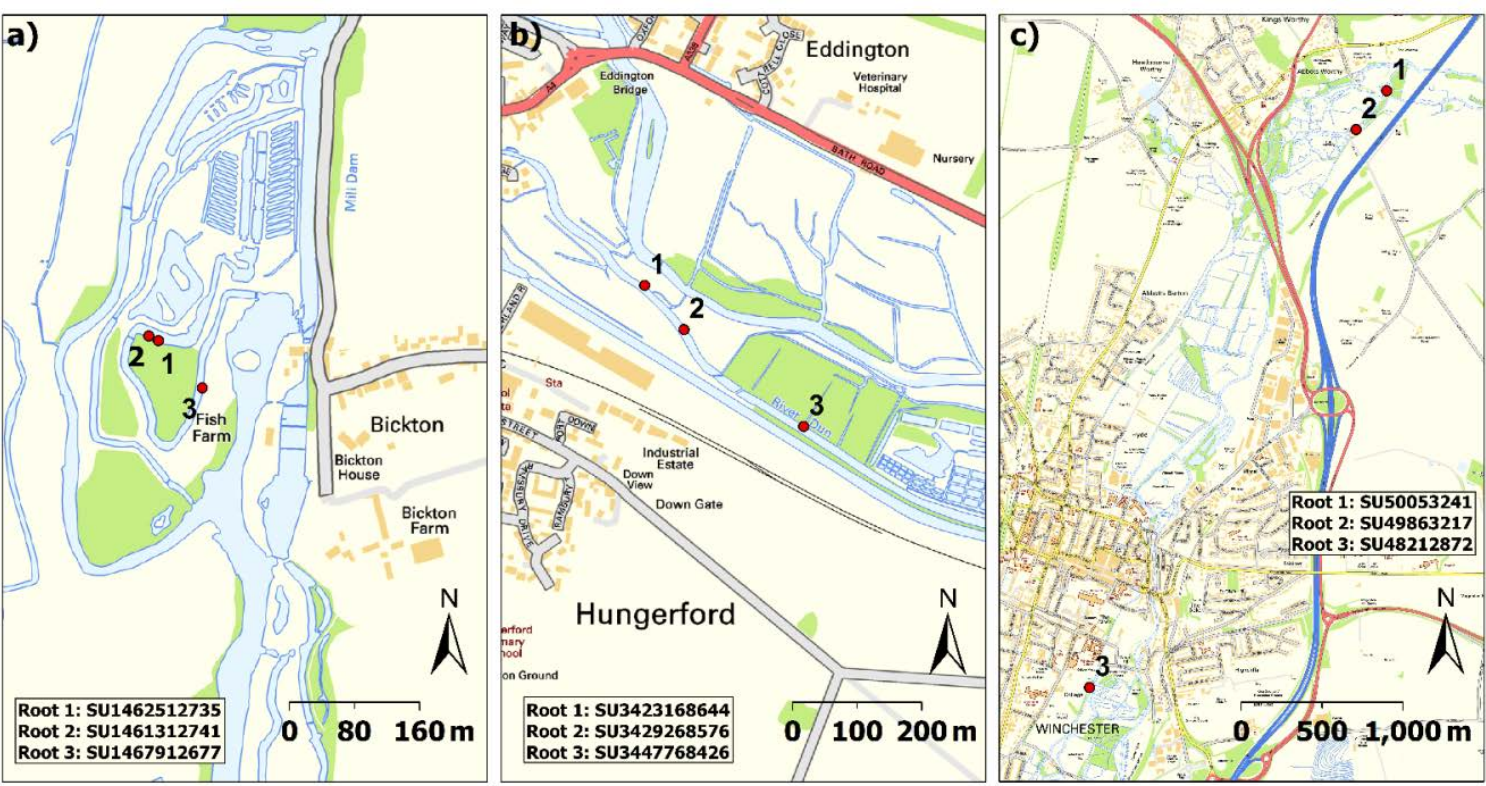
757

758

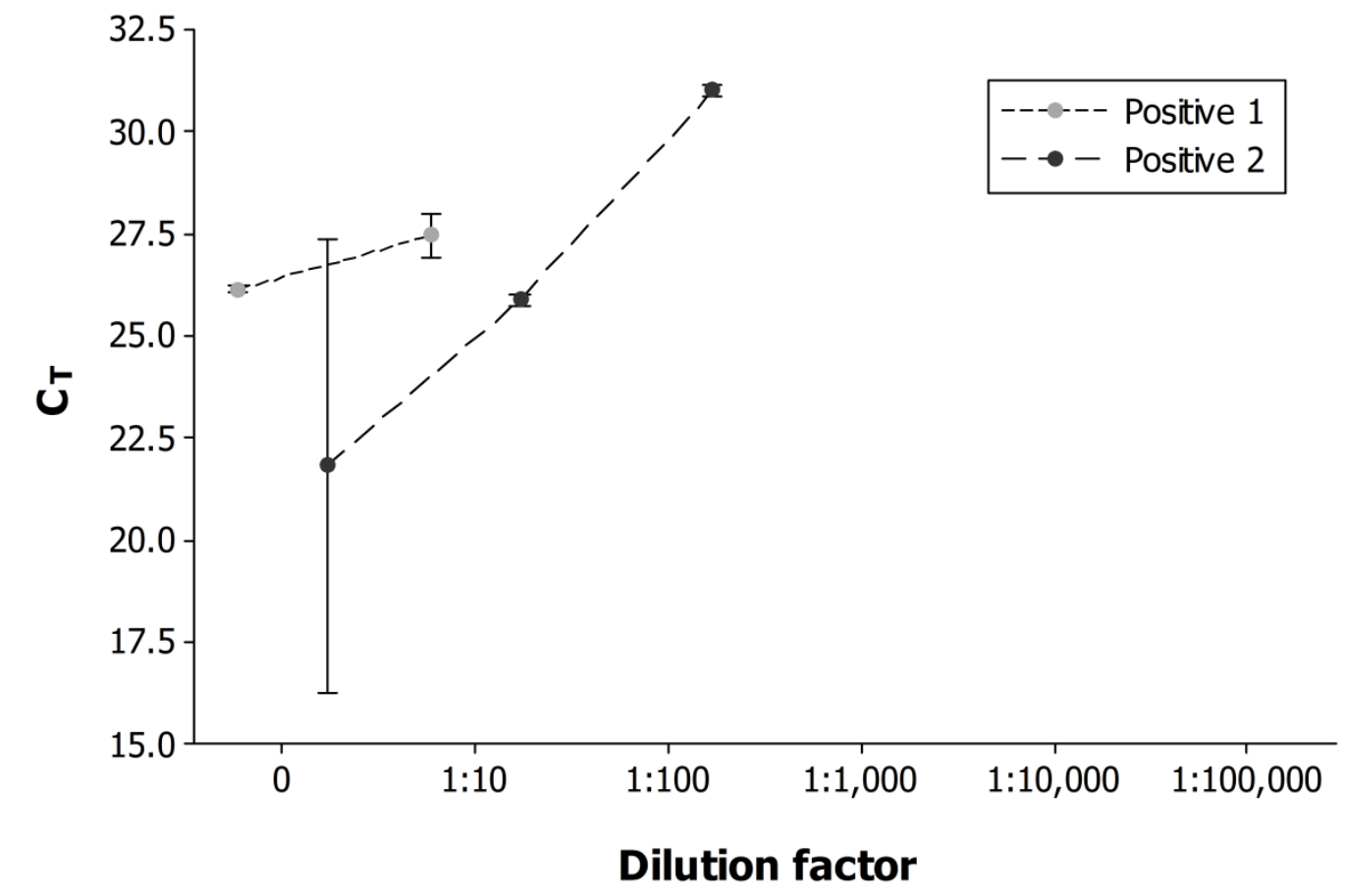


Figure 3

a)

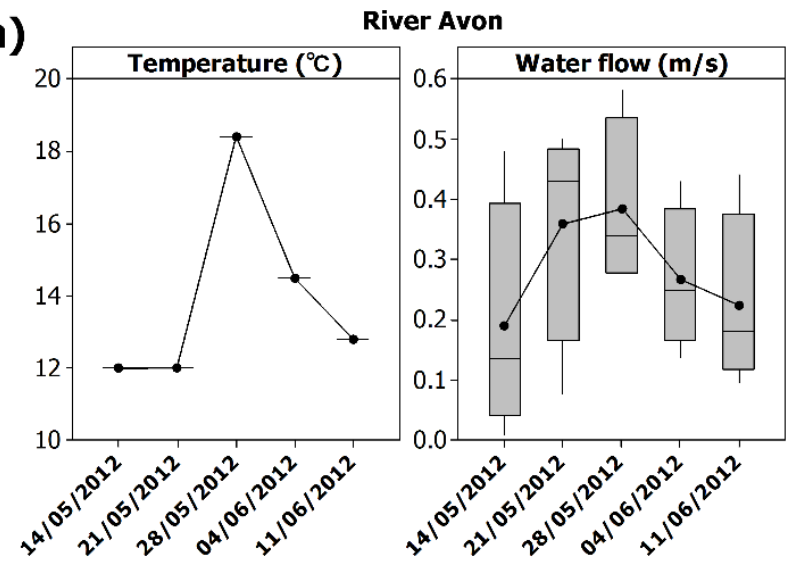

b)

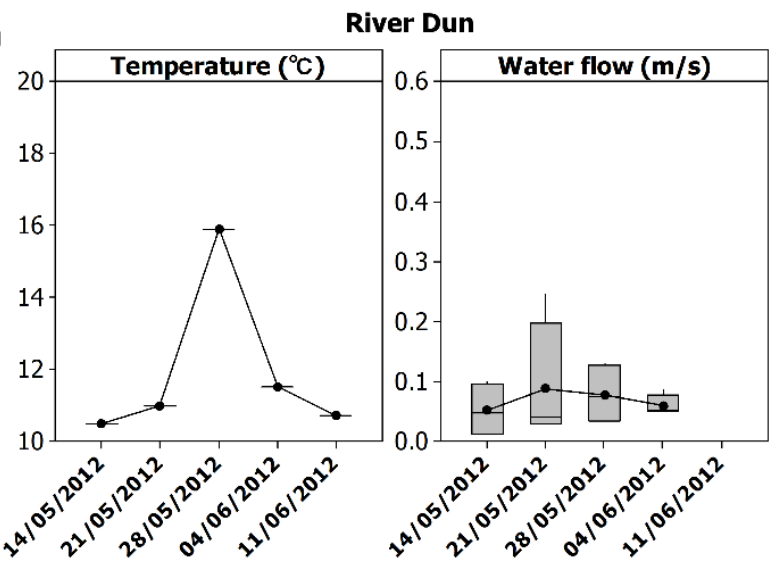

c)

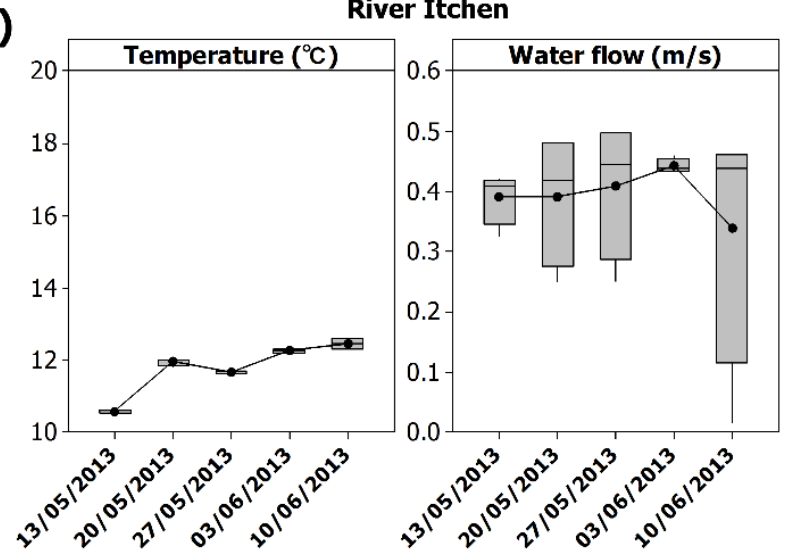

761 
$762 \quad$ Figure 4

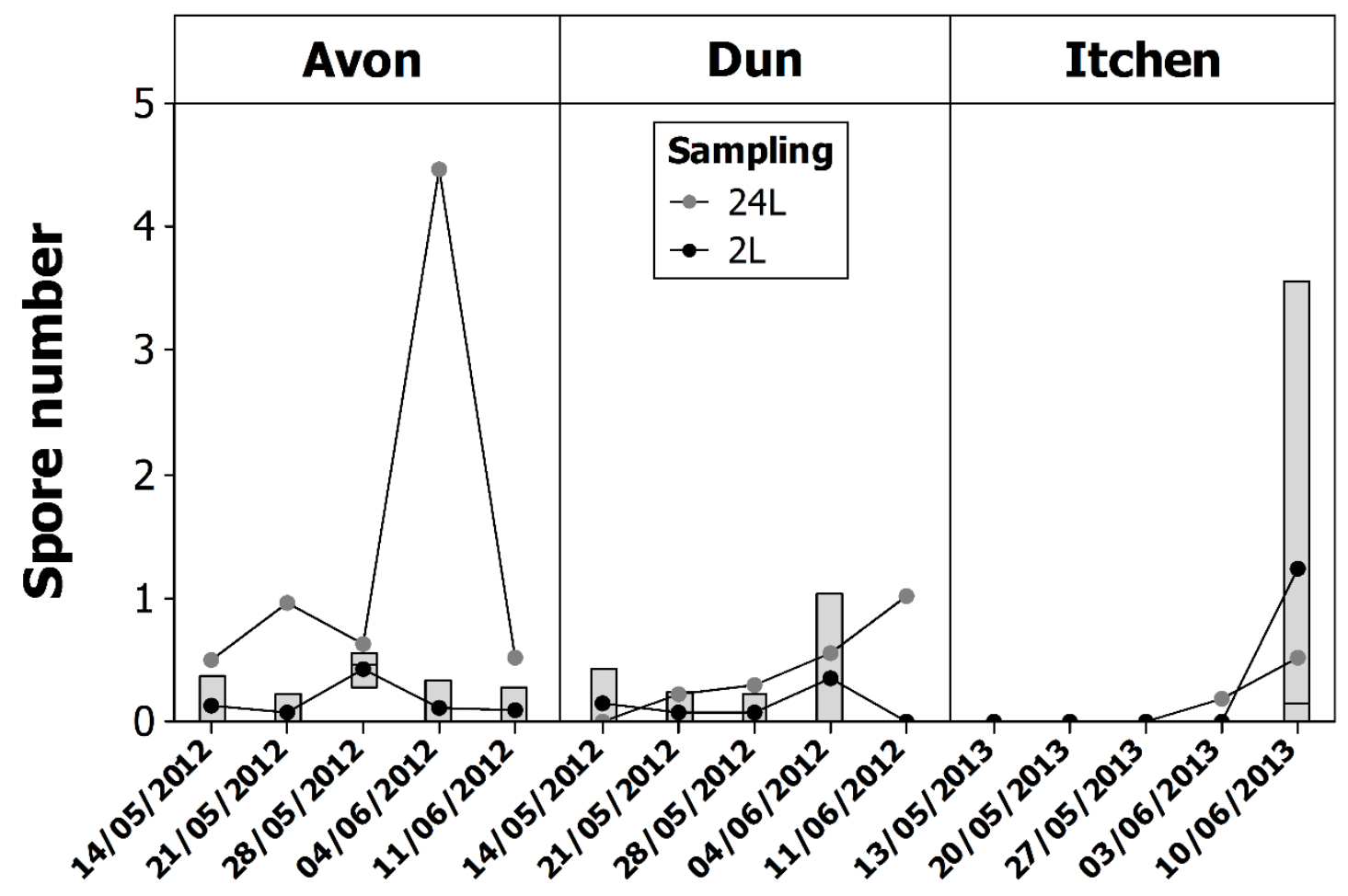


764 Table 1. Statistical results on the various analyses (Likelihood Ratio Tests) undertaken 765 testing the significance of the effect of explanatory variables on parasite presence and 766 abundance in river water samples. $\mathrm{C}_{\mathrm{q}}$ values, spore numbers, water temperature and water 767 flow variables were mean centered for the statistical analyses.

\begin{tabular}{|c|c|c|c|c|c|}
\hline \multirow{2}{*}{\multicolumn{2}{|c|}{ Analysis }} & \multicolumn{4}{|c|}{ Statistical results } \\
\hline & & D & & d.f. & $\mathbf{P}$ \\
\hline \multirow{3}{*}{$\begin{array}{l}\text { Comparison of mean temperature } \\
\text { between rivers: }\end{array}$} & Dun vs. Itchen & \multicolumn{2}{|c|}{0.192} & 1 & 0.778 \\
\hline & Avon vs. Itchen & \multicolumn{2}{|c|}{35.643} & 1 & 0.001 \\
\hline & Avon vs. Dun & \multicolumn{2}{|c|}{30.603} & 1 & 0.016 \\
\hline \multirow{2}{*}{ Effect of roots within a river on: } & Water temperature & \multicolumn{2}{|c|}{0.064} & 6 & 1 \\
\hline & Water flow & \multicolumn{2}{|c|}{0.431} & 6 & $<0.001$ \\
\hline \multirow{2}{*}{$\begin{array}{l}\text { Effect of sample volume on: } \\
\text { (with date included as a random effect) }\end{array}$} & $\mathrm{C}_{\mathrm{q}}$ values & \multicolumn{2}{|c|}{0.913} & 1 & 0.339 \\
\hline & Spore number & \multicolumn{2}{|c|}{0.423} & 1 & 0.516 \\
\hline \multicolumn{2}{|l|}{-} & Odds Ratio & $\chi^{2}$ & d.f. & $\mathbf{P}$ \\
\hline \multicolumn{2}{|c|}{ Effect of sample volume on likelihood of spore detection } & 0.11 & 10.169 & 1 & 0.001 \\
\hline \multicolumn{2}{|c|}{ Effect of water temperature on likelihood of spore detection } & 1.60 & 7.682 & 1 & 0.006 \\
\hline
\end{tabular}


770 Online Table 1. Results from the qPCR primer optimisation using different volume 771 combinations of each primer $(\mathrm{F}=$ forward and $\mathrm{R}=$ reverse $)$ using a sample of a single 772 Tetracapsuloides bryosalmonae spore. The results presented are the mean quantification 773 cycle $\left(\mathrm{C}_{\mathrm{q}}\right)$ values and respective standard deviation.

\begin{tabular}{|c|c|c|}
\hline $\begin{array}{c}\text { F primer volume } \\
(\boldsymbol{\mu L} \text { or } \boldsymbol{\mu M})\end{array}$ & $\begin{array}{c}\text { R primer volume } \\
(\boldsymbol{\mu L} \text { or } \boldsymbol{\mu M})\end{array}$ & $\mathbf{C}_{\mathbf{q}}$ value \pm SD \\
\hline 0.05 & 0.05 & $38.27 \pm 0.69$ \\
\hline 0.05 & 0.50 & $33.95 \pm 0.81$ \\
\hline 0.05 & 1.00 & $33.75 \pm 2.68$ \\
\hline 0.50 & 0.05 & $31.78 \pm 2.27$ \\
\hline 0.50 & 0.50 & $29.49 \pm 2.37$ \\
\hline 0.50 & 1.00 & $28.54 \pm 2.79$ \\
\hline 1.00 & 0.05 & $33.71 \pm 3.41$ \\
\hline 1.00 & 0.50 & $29.51 \pm 2.11$ \\
\hline 1.00 & 1.00 & $28.15 \pm 3.01$ \\
\hline
\end{tabular}


775 Online Table 2. Results from the qPCR inhibition test using an internal positive control 776 (IPC) using 24L and 2L samples. The results presented are the mean quantification cycle $\left(\mathrm{C}_{\mathrm{q}}\right)$ 777 values and respective standard deviation of reactions without eDNA (IPC control) and with eDNA spiked (24L and 2L samples).

779

780

781

782

783

784

785

786

787

788

789

790

791

792

793

794

795

\begin{tabular}{|c|c|c|}
\hline \multicolumn{2}{|c|}{ Sample } & $\begin{array}{c}\text { C } \\
\text { value } \pm \\
\text { SD }\end{array}$ \\
\hline \multicolumn{1}{|c|}{ IPC control } & $16.34 \pm 0.407$ \\
\hline \multirow{7}{*}{ 24L } & Avon & \\
& Root 3 & $16.80 \pm 0.262$ \\
& Week 1 & \\
\cline { 2 - 3 } & Dun & \\
& Root 3 & $16.54 \pm 0.012$ \\
& Week 4 & \\
\cline { 2 - 3 } & Itchen & \\
& Root 3 & $16.81 \pm 0.172$ \\
& Week 3 & \\
\hline \multirow{7}{*}{ 2L } & Avon & \\
& Root 3 & $18.27 \pm 0.289$ \\
& Week 1 & \\
\cline { 2 - 3 } & Dun & \multirow{1}{*}{ Root 2 } \\
& Week 2 & $18.70 \pm 0.525$ \\
\cline { 2 - 3 } & Dun & \\
& Root 2 & $18.23 \pm 0.004$ \\
& Week 3 & \\
\cline { 2 - 3 } & Itchen & \\
& Root 2 & $16.83 \pm 0.078$ \\
& Week 3 & \\
\hline
\end{tabular}


796 Online Table 3. Results from the Tetracapsuloides bryosalmonae qPCR sensitivity test. A

797 1:10 serial dilution of two positive samples (the three negative samples tested were negative 798 at any dilution) was tested. The results presented are the mean quantification cycle $\left(\mathrm{C}_{\mathrm{q}}\right)$ 799 values and respective standard deviation in PCR reactions with and without the addition of 800 bovine serum albumin (BSA). There was no significant difference between $\mathrm{C}_{\mathrm{q}}$ values 801 obtained with and without BSA (Paired t-test: $\mathrm{t}=-0.837$, d.f. $=5, \mathrm{P}=0.441$ ).

\begin{tabular}{|c|c|c|c|}
\hline \multirow{4}{*}{ Sample } & \multirow{2}{*}{ Dilution factor } & \multicolumn{2}{|c|}{$\mathbf{C}_{\mathbf{q}}$ value \pm SD } \\
\cline { 2 - 4 } & & No BSA & BSA \\
\hline \multirow{4}{*}{$\begin{array}{c}\text { Itchen 2L } \\
\text { Root 3 } \\
\text { Week 5 }\end{array}$} & 0 & $21.81 \pm 7.88$ & $21.12 \pm 0.24$ \\
\cline { 2 - 4 } & $1: 10$ & $25.88 \pm 0.18$ & $25.67 \pm 0.34$ \\
\cline { 2 - 4 } & $1: 100$ & $31.00 \pm 0.20$ & $30.76 \pm 0.92$ \\
\cline { 2 - 4 } & $1: 10,000$ & - & - \\
\hline \multirow{4}{*}{$\begin{array}{c}\text { Avon 24L } \\
\text { Root 3 }\end{array}$} & $1: 100,000$ & - & $30.58 \pm 0.87$ \\
\cline { 2 - 4 } Week 4 & 0 & - & - \\
\cline { 2 - 4 } & $1: 10$ & $26.13 \pm 0.12$ & $26.82 \pm 0.09$ \\
\cline { 2 - 4 } & $1: 1,000$ & - & $30.38 \pm 1.29 \pm 0.03$ \\
\cline { 2 - 4 } & $1: 10,000$ & - & - \\
\hline
\end{tabular}


803 Online Table 4. Inter-assay variation (reproducibility) of the Tetracapsuloides bryosalmonae 804 assay using all seven reference standard points. Calculated mean concentration, standard 805 deviation (SD) and coefficient of variation (CV) are given ( $n=4$ runs).

806

\begin{tabular}{|c|c|c|c|}
\hline $\begin{array}{c}\text { Expected standard } \\
\text { concentration (mol/L) }\end{array}$ & $\begin{array}{c}\text { Calculated mean } \\
\text { concentration (mol/L) }\end{array}$ & SD & CV (\%) \\
\hline $1 \mathrm{e}-12$ & $1.14 \mathrm{e}-12$ & $9.56 \mathrm{e}-14$ & 8.40 \\
\hline $1 \mathrm{e}-13$ & $1.12 \mathrm{e}-13$ & $1.07 \mathrm{e}-14$ & 9.60 \\
\hline $1 \mathrm{e}-14$ & $8.92 \mathrm{e}-15$ & $5.28 \mathrm{e}-16$ & 5.91 \\
\hline $1 \mathrm{e}-15$ & $7.87 \mathrm{e}-16$ & $4.15 \mathrm{e}-17$ & 5.28 \\
\hline $1 \mathrm{e}-16$ & $1.02 \mathrm{e}-16$ & $9.03 \mathrm{e}-18$ & 8.88 \\
\hline $1 \mathrm{e}-17$ & $9.25 \mathrm{e}-18$ & $9.28 \mathrm{e}-19$ & 10.03 \\
\hline $1 \mathrm{e}-18$ & $1.26 \mathrm{e}-18$ & $1.11 \mathrm{e}-19$ & 8.78 \\
\hline
\end{tabular}


Online Table 5. Tetracapsuloides bryosalmonae abundance according to sampling method, river, root and trip. Abundance is presented as mean quantification cycle $\left(\mathrm{C}_{\mathrm{q}}\right)$ values and respective standard deviation.

\begin{tabular}{|c|c|c|c|c|c|c|c|}
\hline \multirow{2}{*}{$\begin{array}{l}\text { Sampling } \\
\text { method }\end{array}$} & \multirow{2}{*}{ River } & \multirow{2}{*}{ Root } & \multicolumn{5}{|c|}{$C_{q}$ value $\pm S D$} \\
\hline & & & Week 1 & Week 2 & Week 3 & Week 4 & Week 5 \\
\hline \multirow{9}{*}{$2 \mathrm{~L}$} & \multirow{3}{*}{ Avon } & 1 & - & - & $\begin{array}{c}29.21 \pm \\
0.48\end{array}$ & - & - \\
\hline & & 2 & $\begin{array}{c}29.80 \pm \\
0.18\end{array}$ & - & $\begin{array}{c}29.35 \pm \\
0.16\end{array}$ & - & $\begin{array}{c}30.22 \pm \\
0.13\end{array}$ \\
\hline & & 3 & - & $\begin{array}{c}30.58 \pm \\
0.61\end{array}$ & $\begin{array}{c}29.51 \pm \\
1.22\end{array}$ & $\begin{array}{c}29.97 \pm \\
0.51\end{array}$ & - \\
\hline & \multirow{3}{*}{ Dun } & 1 & - & - & - & $\begin{array}{c}28.27 \pm \\
0.30\end{array}$ & - \\
\hline & & 2 & - & $\begin{array}{c}30.50 \pm \\
0.59\end{array}$ & $\begin{array}{c}30.54 \pm \\
0.05\end{array}$ & - & - \\
\hline & & 3 & $\begin{array}{c}29.63 \pm \\
0.32\end{array}$ & - & - & - & - \\
\hline & \multirow{3}{*}{ Itchen } & 1 & - & - & - & - & $\begin{array}{c}30.27 \pm \\
0.37\end{array}$ \\
\hline & & 2 & - & - & - & - & - \\
\hline & & 3 & - & - & - & - & $\begin{array}{c}25.63 \pm \\
0.27\end{array}$ \\
\hline \multirow{3}{*}{$24 \mathrm{~L}$} & Avon & 3 & $\begin{array}{c}29.38 \pm \\
0.50 \\
\end{array}$ & $\begin{array}{c}27.51 \pm \\
0.37 \\
\end{array}$ & $\begin{array}{c}29.03 \pm \\
0.42 \\
\end{array}$ & $\begin{array}{c}26.17 \pm \\
0.16 \\
\end{array}$ & $\begin{array}{c}29.35 \pm \\
0.53 \\
\end{array}$ \\
\hline & Dun & 3 & - & $\begin{array}{c}30.62 \pm \\
0.05\end{array}$ & $\begin{array}{c}30.13 \pm \\
0.35\end{array}$ & $\begin{array}{c}29.20 \pm \\
0.13\end{array}$ & $\begin{array}{c}28.28 \pm \\
0.64\end{array}$ \\
\hline & Itchen & 3 & - & - & - & $\begin{array}{c}30.75 \pm \\
0.61\end{array}$ & $\begin{array}{c}28.48 \pm \\
0.43\end{array}$ \\
\hline
\end{tabular}




\section{Supplementary figure legends:}

812

813 Online Figure 1. Standard curve derived from a 1:10 serial dilution of an 18S

814 Tetracapsuloides bryosalmonae DNA template showing parasite DNA concentration vs.

815 quantification cycle $\left(\mathrm{C}_{\mathrm{q}}\right)$ value. Each standard was run in duplicate. The curve is significantly 816 linear over seven references from 1e-18 to 1e-12 mol/L. 
Online Figure 1

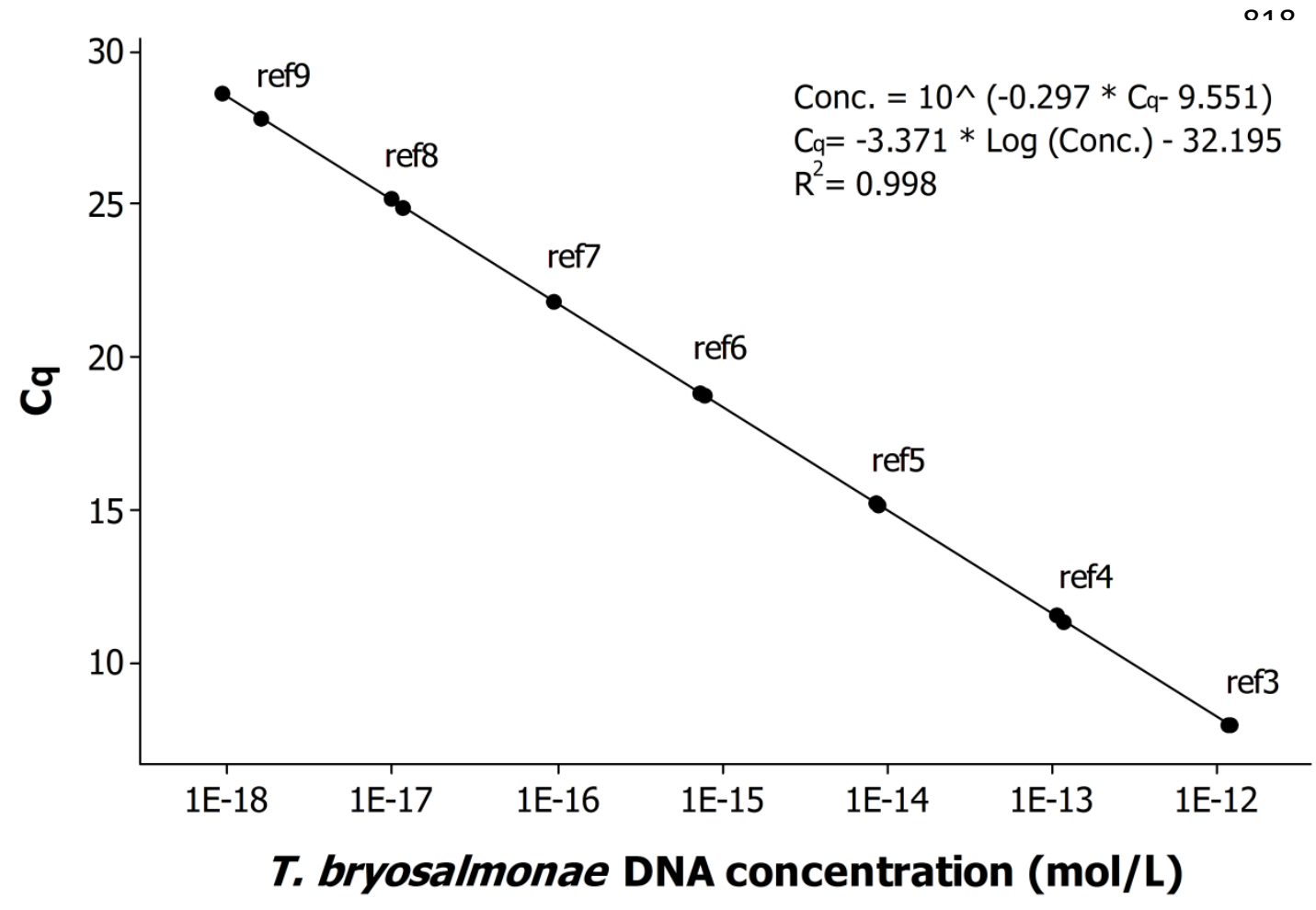

